\title{
PERLAKUAN AKUNTANSI PIUTANG AIR TERHADAP KEWAJARAN NILAI DAN BEBAN PENYISIHAN PIUTANG PADA LAPORAN KEUANGAN PDAM TIRTA KAHURIPAN KABUPATEN BOGOR
}

\author{
Ellyn Octavianty \\ Dosen Tetap Fakultas Ekonomi Universitas Pakuan \\ Lecturer of Economic Faculty at Pakuan University \\ Ria Fajarrohmi \\ Mahasiswa Fakultas Ekonomi Universitas Pakuan \\ Student of Economic Faculty at Pakuan University
}

\begin{abstract}
ABSTRAK
Pelaksanaan penyajian piutang dalam laporan keuangannya PDAM Tirta Kahuripan memiliki ketidaksesuaian pada saat terjadinya transaksi pembayaran kembali piutang yang telah dihapuskan. Pengukuran piutang air dihitung berdasarkan besarnya jasa air serta beban tetap yang dikenakan kepada pelanggan. Pengakuan piutang air diakui ketika proses kalkulasi meter air menjadi rekening air siap ditagih telah dilaksanakan. Penilaian piutang air dinilai sesuai dengan nilai yang dapat ditagih. Penyisihan piutang air dihitung dengan menggunakan metode efisiensi yang berdasarkan pada total tagihan dan total penerimaan piutang. Persentase penyisihan pada tahun berjalan diperoleh dengan menghitung rata-rata persentase penyisihan piutang selama tiga tahun terakhir. Pelaporan piutang usaha disajikan di dalam laporan posisi keuangan. Sedangkan beban penyisihan piutang diakui pada laporan laba rugi pada pos biaya umum dan administrasi.
\end{abstract}

Kata Kunci: Pengukuran Piutang, Pengakuan Piutang, Penilaian Piutang, Penyajian Wajar Piutang Dalam Laporan Keuangan

\begin{abstract}
In the implementation of the presentation of accounts in its financial statements PDAM Tirta Kahuripan have a mismatch at the transaction date of repayment of receivables written-off in which the payment is recognized as other income resulting in the presentation of receivables in the financial statements to be less reasonable. Measurement of water accounts is calculated based on the amount of water services as well as the load remains charged to the customer. Recognition of water receivables are recognized when the calculation process water meter into water ready billed accounts have been implemented. Assessment of water accounts assessed in accordance with the value which can be recovered. Water allowance is calculated using the efficiency based on the total bill and total receivables. The percentage of the allowance for the current year is obtained by calculating the average of the percentage of allowance for three years. Reporting of trade receivables are presented in the statement of financial position. While the provision for accounts receivable are recognized in the income statement in the post of general and administrative expenses.
\end{abstract}

Keywords: Measurement Receivable, Accounts Receivable Recognition, Assessment Receivable, Accounts Receivable In Fair Presentation of Financial Statements

\section{Pendahuluan}

PDAM Tirta Kahuripan Kabupaten

Bogor melakukan penjualan air secara kredit yang mengakibatkan timbulnya suatu tagihan berupa piutang usaha. Piutang usaha merupakan salah satu faktor yang sangat penting untuk diperhatikan karena sifatnya yang dapat dicairkan dalam waktu yang singkat tanpa adanya pencatatan dan pengawasan yang baik, kesalahan dan penyelewengan terhadap piutang tersebut akan mudah terjadi. 
Di dalam menentukan besarnya nilai piutang yang tak tertagih PDAM Tirta Kahuripan Kabupaten Bogor menggunakan metode perhitungan penyisihan piutang tak tertagih berdasarkan metode efisiensi. PDAM Tirta Kahuripan Kabupaten Bogor mengalami ketidaksesuaian perlakuan akuntansi pada saat terjadinya pembayaran kembali piutang yang telah dihapuskan. Perlakuan akuntansi yang berlaku umum pada saat terjadinya pembayaran kembali piutang yang telah dihapuskan adalah dengan mengembalikan kembali piutang yang telah dihapuskan ke dalam pos piutang dan pos penyisihan piutang tak tertagih. Namun pada PDAM Tirta Kahuripan Kabupaten Bogor transaksi tersebut diakui sebagai pendapatan lain-lain. Hal tersebut mengakibatkan penyajian laporan keuangan menjadi tidak wajar dan tidak sesuai dengan prinsip akuntansi yaitu matching cost against revenue principle.

Adapun tujuan penelitian ini adalah sebagai berikut: 1. Untuk mengetahui perlakuan akuntansi piutang air di PDAM Tirta Kahuripan, 2. Untuk mengetahui kewajaran nilai dan beban penyisihan piutang air dalam laporan keuangan PDAM Tirta Kahuripan,dan 3. Untuk mengetahui perlakuan akuntansi piutang air terhadap kewajaran nilai dan beban penyisihan piutang air dalam laporan keuangan PDAM Tirta Kahuripan.

\section{Metode Penelitian}

Jenis penelitian yang digunakan adalah Deskriptif Eksploratif. Metode penelitian yang digunakan oleh penulis adalah Studi Kasus. Teknik penelitian yang digunakan penulis dalam penyusunan skripsi ini adalah Kuantitatif. Unit analisis dalam penelitian ini adalah dyads. Prosedur pengumpulan data yaitu dengan cara penelitian lapangan, seperti wawancara dan observasi serta penelitian kepustakaan. Metode analisis yang digunakan adalah metode analisis Deskriptif Kuantitatif nonstatistik.

\section{Hasil Penelitian}

\subsection{Kebijakan Akuntansi Piutang Air PDAM Tirta Kahuripan}

Piutang disajikan dengan nilai wajar yang dapat direalisasikan. Pada setiap tanggal pelaporan, dilakukan penyisihan kerugian piutang secara kolektif/kelompok pelanggan (pelanggan rumah tangga, niaga, sosial industri, dan lain-lain), yang dibentuk untuk menutup kemungkinan kerugian yang timbul.

Piutang yang telah berumur lebih dari dua tahun dicadangkan penyisihan penurunan nilainya sebesar $100 \%$ dan diusulkan kepada Dewan Pengawas PDAM Tirta Kahuripan untuk dihapus bukukan (write off). Piutang yang telah dihapuskan tersebut secara pembukuan atau akuntansi piutang telah dihapuskan, akan tetapi secara data base daftar pelanggan nominal piutang yang masih belum dibayar oleh pelanggan tetap dicatat.

Terhitung mulai tanggal 1 Januari 2011 PDAM Tirta Kahuripan melakukan perubahan kebijakan akuntansi dengan menerapkan Standar Akuntansi Keuangan Tanpa Akuntabilitas Publik (SAK ETAP).

Pengaruh perubahan kebijakan akuntansi terhadap penyajian kembali laporan keuangan tahun buku 2010, penyisihan piutang yang mengalami perubahan, hal ini dikarenakan PDAM Tirta Kahuripan mengubah metode penyisihan piutang tak tertagih yang semula menggunakan metode umur piutang menjadi metode efisiensi. Manajemen PDAM Tirta Kahuripan menganggap metode tersebut tidak lagi sesuai sehingga terhitung tanggal 1 Januari 
2011 PDAM Tirta Kahuripan mengubah metode umur piutang menjadi metode efisiensi. Metode efisiensi merupakan metode yang memperhitungkan persentase penyisihan piutang dengan menghitung selisih total tagihan piutang dan total penerimaan piutang.

Persentase piutang setiap akhir tahun dihasilkan dari tiga tahun buku sebelumnya, sehingga persentase penyisihan tahun 2011 merupakan hasil dari rata-rata persentase penyisihan piutang tahun 2008, 2009 dan 2010. Akibat adanya perubahan metode penyisihan piutang ini, maka menghasilkan perubahan saldo penyisihan piutang pada tahun 2010. Nominal saldo penyisihan piutang audited tahun 2010 sebelum mengalami perubahan metode penyisihan adalah sebesar $\mathrm{Rp}$ 2.676.831.358 dan berubah menjadi Rp 2.975.800.933 setelah dihitung ulang dengan metode efisiensi.

Terdapat perubahan besarnya saldo penyisihan piutang yang terjadi pada saat dirubahnya metode umur piutang menjadi metode efisiensi. Selisih sebesar Rp 298.969.575 diperoleh sebagai akibat dari perubahan metode penyisihan yang digunakan.

Kebijakan mengenai pelaporan piutang pada laporan keuangan Perusahaan Daerah Air Minum (PDAM) Tirta Kahuripan Kabupaten Bogor disajikan pada laporan posisi keuangan (Neraca) dan laporan laba rugi pada pos biaya umum dan administrasi untuk pengakuan beban penyisihan piutang. Laporan keuangan Perusahaan Daerah Air Minum (PDAM) Tirta Kahuripan Kabupaten Bogor disajikan berdasarkan Standar Akuntansi Keuangan Entitas Tanpa Akuntabilitas Publik (SAK ETAP). Perhitungan hasil usaha dan posisi keuangan disusun berdasarkan konsep biaya perolehan dan akrual. Pencatatan akuntansi dan pelaporan menggunakan mata uang rupiah dengan perlakuan pembulatan menjadi satu rupiah penuh.

\subsection{Jenis Piutang PDAM Tirta Kahuripan Kabupaten Bogor \\ PDAM Tirta Kahuripan melakukan} penjualan produknya dengan menggunakan sistem piutang. Penjualan secara piutang ini diberikan kepada pelanggan untuk memanfaatkan pemakaian air pada bulan ini dan akan dibayar pada bulan berikutnya. Di dalam PDAM Tirta Kahuripan terdapat 3 jenis piutang usaha, yaitu: piutang air, piutang non air dan piutang lain-lain.

Dari ketiga jenis piutang yang terdapat di PDAM Tirta Kahuripan, penulis mengobservasi penerapan akuntansi piutang air, karena piutang air timbul akibat dari pemakaian jasa air yang merupakan kegiatan utama PDAM Tirta Kahuripan.

Piutang air adalah tagihan atau klaim PDAM Tirta Kahuripan kepada pelanggan baik perusahaan, instansi, maupun perseorangan. Piutang ini timbul akibat dari pemakaian jasa air yang telah digunakan pelanggan selama satu bulan sebelumnya. Piutang air merupakan pendapatan inti dari perusahaan. Karena piutang ini muncul akibat dari penyerahan jasa berupa penyediaan air bersih kepada pelanggan.

\subsection{Perlakuan Akuntansi Piutang Air}

Terdapat tiga perlakuan akuntansi di dalam piutang air PDAM Tirta Kahuripan Kabupaten Bogor yaitu: pengukuran piutang, pengakuan piutang dan penilaian piutang.

Pengukuran piutang PDAM Tirta Kahuripan Kabupaten Bogor, timbul akibat dari penjualan jasa air. Adapun 
komponen perhitungan jasa air di dalam PDAM Tirta Kahuripan Kabupaten Bogor adalah berupa harga air dan beban tetap. Penjualan jasa air berasal dari total kenaikan meter air pelanggan pada bulan yang bersangkutan. Pengukuran piutang air dikalkulasikan dari jumlah pemakaian/jumlah meter air yang digunakan pelanggan per $10 \mathrm{~m}^{3}$, kemudian dikalikan dengan tarif per golongan pelanggan setelah itu dijumlahkan dengan biaya beban tetap yang besarannya disesuaikan dengan ukuran instalasi meter air yang digunakan.

Pengakuan piutang di PDAM Tirta Kahuripan Kabupaten Bogor diakui ketika pembacaan meter dilakukan. Pembacaan meter dilakukan setiap bulan oleh setiap cabang-cabang pelayanan. Dari hasil pembacaan meter akan diketahui kewajaran dari pemakaian berdasarkan rata-rata pemakaian pelanggan. Bagian pembukuan akan menjurnal dan mengakui hasil kalkulasi tersebut sebagai piutang.

Di dalam penilaian piutang, piutang di sajikan dalam nilai realisasi bersih. Untuk itu setiap akhir periode akan dihitung penyisihan atau cadangan kerugian piutang yang sesuai. Perhitungan penyisihan piutang tersebut menggunakan metode efisiensi. Metode efisiensi menghasilkan persentase penyisihan sebagai dasar perhitungan.

Besarnya penyisihan piutang pada akhir tiap tahun ditentukan dengan menghitung rata-rata persentase efisiensi dari 3 (tiga) tahun terakhir. Berikut perhitungan persentase efisiensi dan akumulasi penyisihan piutang pada tahun 2011:

Tabel 3.1.

Persentase Efisiensi Dan Akumulasi Penyisihan Piutang Pada Tahun 2011

Percentage Of Efficiency And Allowance For Receivable Period 2011

\begin{tabular}{|c|c|c|c|c|c|c|}
\hline \multirow[t]{2}{*}{ No } & \multirow{2}{*}{$\begin{array}{c}\text { Kode } \\
\text { Kelompok }\end{array}$} & \multirow[t]{2}{*}{ Kelompok Pelanggan } & \multicolumn{4}{|c|}{$\%$ Penyisihan } \\
\hline & & & 2008 & 2009 & 2010 & $\begin{array}{c}\text { Rata-Rata }(\%) \\
2011\end{array}$ \\
\hline 1 & $\mathrm{I}$ & SOSIAL UMUM & $5 \%$ & $2 \%$ & $4 \%$ & $4 \%$ \\
\hline 2 & IIA & SOSIAL KHUSUS & $5 \%$ & $4 \%$ & $6 \%$ & $5 \%$ \\
\hline 3 & IIB & RSS & $11 \%$ & $15 \%$ & $31 \%$ & $19 \%$ \\
\hline 4 & IIIA & R.SEDERHANA & $7 \%$ & $2 \%$ & $3 \%$ & $4 \%$ \\
\hline 5 & IIIB & R. MENENGAH & $7 \%$ & $7 \%$ & $7 \%$ & $7 \%$ \\
\hline 6 & IIIC & INSTANSI PEMERINTAH & $2 \%$ & $20 \%$ & $18 \%$ & $13 \%$ \\
\hline 7 & IVA & R. MEWAH/KANTOR & $6 \%$ & $2 \%$ & $3 \%$ & $4 \%$ \\
\hline 8 & IVB & NIAGA KECIL & $6 \%$ & $2 \%$ & $3 \%$ & $4 \%$ \\
\hline 9 & IVC & INDUSTRI KECIL & $3 \%$ & $0 \%$ & $0 \%$ & $1 \%$ \\
\hline 10 & IVD & NIAGA BESAR & $12 \%$ & $1 \%$ & $2 \%$ & $5 \%$ \\
\hline 11 & IVE & INDUSTRI BESAR & $0 \%$ & $-3 \%$ & $0 \%$ & $-1 \%$ \\
\hline 12 & - & Khusus & $2 \%$ & $1 \%$ & $3 \%$ & $2 \%$ \\
\hline 13 & - & Karyawan & $5 \%$ & $0 \%$ & $0 \%$ & $2 \%$ \\
\hline
\end{tabular}

Persentase yang diperoleh dari tahun 2008-2010 digunakan sebagai dasar persentase penyisihan pada tahun 2011. Setelah diperoleh persentase penyisihan

JAFE (Jurnal Ilmiah Akuntansi Fakultas Ekonomi)

Volume 1 No. 1 Tahun 2015, Hal. 20-26 
pada tahun 2011 maka persentase tersebut digunakan untuk menghitung besarnya penyisihan piutang pada tahun 2011 .

Akumulasi penyisihan merupakan jumlah penyisihan piutang ditambah dengan jumlah piutang yang akan dihapuskan. Setelah diketahui total cadangan penyisihan piutang maka dapat diketahui besarnya kenaikan beban penyisihan piutang tahun 2011. Adapun rumus menghitung beban penyisihan piutang adalah:

Tabel 3.2.

Beban Penyisihan Piutang period 2011

Allowance For Receivable Expenses period 2011

\begin{tabular}{|l|c|}
\hline URAIAN & JUMLAH \\
\hline Saldo Piutang Awal & 2.975 .800 .933 \\
\hline $\begin{array}{l}\text { Penghapusan (Keputusan Dir No. } \\
\text { 953/sk.80/PDAM/HUK/VI/2011) }\end{array}$ & $\underline{(1.623 .701 .606)}$ \\
\hline & 1.352 .099 .327 \\
\hline $\begin{array}{l}\text { Hasil Opname 31 Desember 2011 (Saldo Piutang } \\
\text { Akhir) }\end{array}$ & $\underline{\underline{1.166 .128 .795)}}$ \\
\hline Beban Penyisihan Piutang & $(185.970 .532)$ \\
\hline
\end{tabular}

Setelah diperoleh beban penyisihan maka bagian pembukuan akan mengakui penyisihan tersebut dengan jurnal sebagai berikut:

\begin{tabular}{|l|c|c|}
\hline \multicolumn{1}{|c|}{ Uraian } & Debet & Kredit \\
\hline Beban Penyisihan Piutang & $\mathrm{Rp} \mathrm{185.970.532}$ & \\
\hline Cadangan Penyisihan Piutang & & $\mathrm{Rp} \mathrm{185.970.532}$ \\
\hline
\end{tabular}

Piutang yang dimasukkan ke dalam daftar normatif merupakan piutang rekening air di atas 2 tahun dengan persentase penyisihan $100 \%$ yang sebelumnya telah dikelompokkan kedalam piutang ragu-ragu. Pada tahun 2011 piutang yang dihapuskan berdasarkan
Keputusan

Dir 953/sk.80/PDAM/HUK/VI/2011 adalah sebesar Rp 1.623.701.606. Berikut jurnal penghapusan piutang pada Perusahaan Daerah Air Minum (PDAM) Tirta Kehuripan Kabupaten Bogor:

\begin{tabular}{|l|c|c|}
\hline \multicolumn{1}{|c|}{ Uraian } & Debet & Kredit \\
\hline Cadangan Penyisihan Piutang & $\mathrm{Rp} 1.623 .701 .606$ & \\
\hline Piutang Usaha & & $\mathrm{Rp} \mathrm{1.623.701.606}$ \\
\hline
\end{tabular}

Pada PDAM Tirta Kahuripan Kabupaten Bogor pembayaran tersebut diakui sebagai pendapatan lain-lain di sisi kredit dan kas/Bank pada sisi debet. Hal ini dikarenakan banyaknya jumlah pelanggan yang dimiliki PDAM Tirta Kahuripan Kabupaten Bogor, sehingga mengakibatkan sulitnya memunculkan 
kembali piutang yang telah dihapuskan dan membuat jurnal pelunasannya.

Sedangkan perlakuan akuntansi yang seharusnya berdasarkan Standar Akuntansi yang berlaku umum adalah membalik ayat jurnal ketika penghapusan piutang yaitu Piutang Usaha di sisi debet dan Penyisihan Piutang Tak Tertagih di sisi kredit, selain itu juga mengakui piutang yang dapat di tagih tersebut dengan membuat ayat jurnal Kas di sisi debet dan Piutang Usaha di sisi Kredit, dengan begitu dapat terlihat pada saat penyajian total piutang di dalam Laporan Posisi Keuangan berapa total piutang yang dapat tertagih dan dapat direalisasikan.

\subsection{Penyajian Laporan Keuangan PDAM Tirta Kahuripan}

Penyajian piutang air pada laporan keuangan PDAM Tirta Kahuripan Kabupaten Bogor disajikan pada laporan posisi keuangan sisi aset lancar dan laporan laba rugi dalam pos biaya umum dan administrasi. Di dalam laporan posisi keuangan, piutang air disajikan bersamaan dengan piutang non air. Hal ini dikarenakan piutang air dan piutang non air diklasifikasikan ke dalam piutang usaha. Penyajian piutang usaha disajikan dengan lengkap yaitu total piutang usaha bruto, cadangan penyisihan piutang dan piutang usaha neto. Sedangkan di dalam laporan laba rugi, beban penyisihan piutang dikategorikan ke dalam pos biaya umum dan administrasi.

\section{Kesimpulan}

1. Perlakuan akuntansi piutang air pada PDAM Tirta Kahuripan Kabupaten Bogor terdiri dari: a. Pengukuran piutang air dilakukan dengan memperhitungkan pemakaian jasa air oleh pelanggan, b. Perhitungan dilakukan dengan tarif yang berbeda tiap golongan pelanggan dan tiap 10 $\mathrm{m}^{3}$ pemakaian air. Selain dari jasa air yang digunakan, jumlah tagihan juga merupakan akumulasi dari penggunaan jasa air dan biaya beban tetap. Pengakuan piutang diakui setelah pembacaan meter dilakukan, dan c. Penilaian piutang dilakukan tiap tanggal pelaporan dengan menghitung penyisihan piutang tak tertagih menggunakan metode efisiensi dengan dasar rata-rata persentase penyisihan tiga tahun berturut-turut. Jumlah akumulasi penyisihan piutang tahun 2011 sebesar Rp 1.166.128.794, dengan biaya penyisihan piutang tahun 2011 sebesar $\quad \mathrm{Rp} \quad 185.970 .532$. Menentukan piutang-piutang yang telah berumur lebih dari 2 tahun untuk dilakukan penghapusan piutang. Piutang-piutang yang telah dihapus dari pembukuan akan tetap tercatat pada daftar pelanggan jika suatu saat piutang tersebut dibayarkan kembali maka total tagihan beserta denda masih tetap tercatat. Piutang yang telah dihapus dan dibayarkan kembali oleh pelanggan diakui sebagai pendapatan lain-lain. Akibat dari perlakuan akuntansi ini, penilaian piutang menjadi kurang optimal dikarenakan penerimaan kembali piutang yang telah dihapuskan seharusnya mempengaruhi jumlah penerimaan piutang pada tahun yang bersangkutan dan berpengaruh pula pada besarnya persentase penyisihan piutang.

2. Nilai dan beban penyisihan piutang pada laporan posisi keuangan dan laporan laba rugi PDAM Tirta Kahuripan Kabupaten Bogor disajikan secara wajar dengan dasar 
pengukuran, pengakuan dan penilaian beban penyisihan sesuai dengan SAK ETAP dan Keputusan Menteri Keuangan. Di dalam pengukuran, beban penyisihan dihitung berdasarkan kenaikan penyisihan piutang awal tahun dan penyisihan piutang akhir tahun setelah dikurangi dengan besarnya piutang yang telah dihapuskan. Pengakuan beban penyisihan piutang diakui setiap akhir tahun buku dan dilaporkan kenaikannya pada laporan laba rugi tahun berjalan. Sedangkan akumulasi penyisihan cadangan piutang dilaporkan pada laporan posisi keuangan.

3. Perlakuan akuntansi piutang air pada saat pengukuran, pengakuan dan penilaian piutang pada PDAM Tirta Kahuripan Kabupaten Bogor menunjang kewajaran nilai dan beban penyisihan pada laporan keuangan yang telah disajikan. Atas prinsip akuntansi yang digunakan, kepatuhan terhadap kebijakan akuntansi yang ada di PDAM Tirta Kahuripan Kabupaten Bogor serta kesesuaian kebijakan akuntansi PDAM Tirta Kahuripan Kabupaten Bogor dengan SAK ETAP dan Keputusan Menteri Keuangan, laporan posisi keuangan PDAM Tirta Kahuripan Kabupaten Bogor per 31 Desember 2011 dan laporan laba rugi PDAM Tirta Kahuripan Kabupaten Bogor untuk tahun yang berakhir $31 \quad$ Desember 2011 disajikan secara wajar dalam hal penyajian nilai dan beban penyisihan piutang yang material.

\section{Daftar Pustaka}

Ahmad Syafi'i Syakur. 2009. Intermediate Accounting Dalam Perspektif Lebih
Luas. Penerbit AV Publisher, Jakarta.

Duchac, Warren, Reeve. 2009. Financial Accounting. South-Western Cengage Learning, USA.

Hery, 2009. Akuntansi Keuangan Menengah 1. PT Bumi Aksara, Jakarta.

Imam Santoso. 2007. Akuntansi Keuangan Menengah. Penerbit PT Refika Aditama, Bandung.

Institut Akuntan Publik Indonesia. 2009. Standar Akuntansi Keuangan Per 1 Juli 2009. Penerbit Salemba Empat, Jakarta.

Institut Akuntan Publik Indonesia. 2009. Standar Akuntansi Keuangan Entitas Tanpa Akuntabilitas Publik. Penerbit Ikatan Akuntansi Indonesia, Jakarta.

Kieso, Donald E., Weygandt, Jerry J., Warfield, Terry D.

Komite Standar Akuntansi Pemerintahan. 2007. Standar Akuntansi Pemerintahan. Cetakan I. Pustaka Yustisia, Yogyakarta.

Lerner Joel J. 2007. Theory and Problems of Bookeeping and Accounting, Fourth Edition. McGraw-Hill, New York.

Pagach, Norton, Diamond. 2007. Intermediate Accounting: Financial, Reporting and Analysis. Second Edition. Houghton Mifflin Company, USA.

Roshayani, Umar L., Siti Maznah Mohd. Arif. 2007. Financial Accounting An Introduction, Second Edition. McGraw Hill, Selangor Malaysia. 